\title{
Pengaruh Nilai EC Berbagai Pupuk Cair Majemuk Terhadap Pertumbuhan Vegetatif Kangkung Darat Pada Soilless Culture
}

\section{The Effect of EC Value of Various Liquid Compound Fertilizers on Vegetative Growth of Ground Water Spinach in Soilless Culture}

\author{
Suseno*, Nugraheni Widyawati \\ Department of Agrotechnology, Faculty of Agriculture and Business, Universitas Kristen Satya Wacana, Salatiga, Indonesia \\ ${ }^{*}$ Corresponding author: senomavs87@gmail.com
}

Received: July 19, 2019; Accepted: September 24, 2019; Published: April 1, 2020

\begin{abstract}
Ground water spinach is one of the vegetable plants that has high economic and nutritional value. Soilless culture becomes an alternative in soilless crop cultivation by using substrate or water media. The purpose of this study was to determine the value of Electrical Conductivity $(E C)$ of compound liquid fertilizer on vegetative growth and to found the best type of compound liquid fertilizer for ground water spinach. The research was conducted in the experimental garden of Faculty of Agriculture and Business, Universitas Kristen Satya Wacana, Salatiga, Central Java, with an altitude 500 meters above sea level. The study was conducted in June - July 2018. The study used an experimental method with a Randomized Block Design (RBD), consisting of 5 treatments with four types of fertilizers and one control (without fertilizer), each treatment was repeated 5 times. The types of fertilizers tested were AB mix (Inorganic), Hortigro A (Inorganic), Multitonic (Organic), and Supermes (Organic). The results showed that fertilization caused an increase in the EC value of hydroponic solutions. $A B$ mix fertilizer (inorganic) with $E C$ 1,58-2,32 $\mathrm{mS} / \mathrm{cm}$ gives the best results on plant height $(30.01 \mathrm{~cm})$, number of leaves $\left(8.1\right.$ strands), leaf area $\left(13.16 \mathrm{~cm}^{2}\right)$, diameter stems $(5.63 \mathrm{~mm})$, and top fresh weight $(388.85 \mathrm{~g})$.
\end{abstract}

Key words: hidroponic, organic, osmotic pressure

Cite this as: Suseno, \& Widyawati, N. (2020). Pengaruh Nilai EC Berbagai Pupuk Cair Majemuk Terhadap Pertumbuhan Vegetatif Kangkung Darat Pada Soilless Culture. Agrosains : Jurnal Penelitian Agronomi 22(1): 12-15. DOI: http://dx.doi.org/10.20961/agsjpa.v22i1.32510

\section{PENDAHULUAN}

Kangkung darat (Ipomoea reptans P.) menjadi salah satu sayur yang banyak dikonsumsi di Indonesia, tanaman ini banyak diperjual-belikan di pasar tradisional ataupun modern. Kangkung memiliki banyak gizi yang bermanfaat bagi tubuh antara lain energi, protein, lemak, kalsium, fosfor, zat besi, vitamin $A$, vitamin $B 1$, vitamin $C$, dan karbohidrat (Swastini, 2015). Kangkung merupakan tanaman yang dikonsumsi pada bagian batang dan daun, sehingga pertumbuhan pada fase vegetatif sangat perlu diperhatikan.

Soilless culture merupakan budidaya tanaman secara modern tanpa menggunakan tanah, yaitu dengan media substrat ataupun media air (Savvas et al. 2013). Jika dibandingkan pertanian konvensional, soilless culture memiliki kelebihan antara lain penggunaan lahan lebih efisien, kuantitas dan kualitas produksi lebih tinggi dan lebih bersih, penggunaan pupuk dan air lebih efisien, serta pengendalian hama dan penyakit lebih rendah. Ditengah penggunaan lahan pertanian yang dijadikan non pertanian saat ini, hidroponik menjadi salah satu solusi untuk budidaya tanaman.
Dalam sistem hidroponik, salah satu hal yang perlu diperhatikan yaitu pemakaian nutrisi. Nutrisi dapat diberikan dari bahan organik ataupun anorganik yang berasal dari pupuk racikan ataupun yang tersedia di pasaran (Tim Karya Tani Mandiri, 2010). Pupuk cair majemuk dapat menghasilkan tingkat Konduktivitas listrik/Electrical Conductivity (EC) yang berbeda karena perbedaan komposisi unsur hara. EC dalam hidroponik penting diperhatikan karena dapat mempengaruhi metabolisme tanaman seperti kecepatan fotosintesis, aktivitas enzim, dan potensi penyerapan ion-ion larutan oleh akar (Sutiyoso, 2004). Semakin tinggi garam dalam larutan nutrisi dan air, semakin tinggi EC (Wibowo et al., 2017). Konsentrasi garam yang tinggi dapat merusak akar tanaman dan mengganggu serapan nutrisi dan air. Menurut Dyka (2018), nilai EC yang terlalu tinggi menghambat serapan hara dengan meningkatkan tekanan osmotik, sedangkan nilai EC rendah dapat mempengaruhi kesehatan tanaman. Nilai EC akan mempengaruhi pertumbuhan tanaman, sehingga nilai EC setiap jenis pupuk perlu diketahui terutama pupuk cair untuk sistem hidroponik. Tujuan penelitian ini adalah untuk mempelajari pengaruh 
nilai EC pupuk cair majemuk terhadap pertumbuhan kangkung darat dan mencari jenis pupuk yang memberikan pertumbuhan terbaik pada kangkung darat. Penelitian ini diharapkan dapat menambah pengetahuan serta memberikan rekomendasi untuk pemilihan pupuk cair majemuk pada budidaya hidroponik.

\section{BAHAN DAN METODE}

Penelitian ini dilaksanakan bulan Juni - Juli 2018 di kebun percobaan Fakultas Pertanian dan Bisnis, Universitas Kristen Satya Wacana (UKSW) Salatiga, Jawa Tengah dengan ketinggian 500 meter dpl. Alat penelitian yang digunakan adalah $\mathrm{pH}$ meter, EC meter, termometer dan hygrometer merk HC-2, gelas ukur $500 \mathrm{ml}$ dan oven. Bahan yang digunakan dalam penelitian adalah benih kangkung var. Oriental Nana, pupuk cair (AB mix, Hortigro A, Multitonik, Supermes) Penelitian ini dilakukan menggunakan metode percobaan dengan Rancangan Acak Kelompok (RAK), terdiri atas 5 perlakuan dengan empat jenis pupuk dan satu kontrol (tanpa pupuk), masing - masing perlakuan diulang sebanyak 5 kali. Jenis pupuk yang diuji adalah pupuk $A B$ mix (Anorganik), Hortigro A (Anorganik), Multitonik (Organik), dan Supermes (Organik). Setiap satuan percobaan terdiri dari 3 wadah penelitian, sehingga total wadah yaitu 75 wadah penelitian. Pada setiap wadah terdapat 30 tanaman kangkung. Berikut adalah perlakuan yang dicoba $\mathrm{PO}$ : tanpa pupuk (kontrol), P1: Pupuk AB mix (Anorganik), P2: Pupuk Hortigro A (Anorganik), P3: Pupuk Multitonik (Organik), P4: Pupuk Supermes (Organik). Dosis pupuk yang digunakan yaitu sesuai dosis anjuran pupuk pada kemasan.

Soilless culture yang diterapkan adalah hidroponik sistem rakit apung yang disederhanakan. Parameter pengukuran pertumbuhan adalah tinggi tanaman, jumlah daun, luas daun, diameter batang, dan berat segas atas tanaman. Pengamatan dilakukan secara non destruktif yaitu dengan pengukuran tinggi tanaman dan jumlah daun setiap 7 hari sekali selama 35 hari, pengukuran diameter batang, luas daun, dan berat segar dilakukan pada saat panen (35 HST). Pengukuran nilai EC dilakukan setiap 3 hari sekali, yaitu pada awal penggantian pupuk dan diakhir larutan digunakan. Data hasil percobaan dianalisis menggunakan Analisis of Varians (ANOVA), jika diketahui berbeda nyata maka dilanjutkan dengan Uji Beda Nyata Jujur (BNJ) selang kepercayaan $95 \%$.

\section{HASIL DAN PEMBAHASAN \\ Nilai EC yang Dihasilkan Berbagai Perlakuan Jenis Pupuk Cair Majemuk}

Konduktivitas listrik (EC) larutan hara di hidroponik dapat mewakili jumlah total garam dalam larutan nutrisi untuk tanaman. Pada Tabel 1. setiap perlakuan yang diuji dengan dosis masing - masing kemasan menghasilkan rentang nilai EC yang berbeda. Nilai EC dipengaruhi oleh komposisi dan konsentrasi dari nutrisi yang dilarutkan, perbedaan jumlah garam - garam dari nutrisi yang terlarut akan menyebabkan nilai EC tinggi ataupun rendah.
Kebutuhan tingkat kepekatan larutan nutrisi tanaman sayuran yaitu EC sekitar 1,5-2,5 mS/cm. Jika melihat Tabel 1. maka hanya perlakuan $A B$ mix yang menghasilkan nilai EC yang tinggi dan sesuai untuk kebutuhan sayur, sedangkan perlakuan lain menghasilkan nilai EC dibawah rekomendasi. Semakin tinggi nilai EC menandakan semakin banyak jumlah garam terlarut, hal ini berarti perlakuan $A B$ mix banyak unsur hara yang larut dan tersedia untuk digunakan tanaman. Sebaliknya semakin sedikit jumlah garam terlarut maka semakin sedikit pula unsur hara yang dapat diserap oleh tanaman, hal ini ditandai dengan rendahnya nilai EC. Nilai EC yang terlalu tinggi menghambat serapan hara dengan meningkatkan tekanan osmotik, sedangkan nilai EC yang rendah dapat mempengaruhi kesehatan tanaman (Ibrahim et al. 2015).

Tabel 1. Perlakuan, Dosis dan Rataan Nilai EC yang Dihasilkan Berbagai Perlakuan Jenis Pupuk Cair Majemuk

\begin{tabular}{cccc}
\hline Perlakuan & $\begin{array}{c}\text { Dosis } \\
\text { penggunaan }\end{array}$ & $\begin{array}{c}\text { EC awal } \\
(\mathbf{m S} / \mathbf{c m})\end{array}$ & $\begin{array}{c}\text { EC akhir } \\
(\mathbf{m S} / \mathbf{c m})\end{array}$ \\
\hline $\begin{array}{c}\text { Tanpa pupuk } \\
\text { (Kontrol) }\end{array}$ & $300 \mathrm{ml}$ air & & \\
$\begin{array}{c}\text { Ab mix } \\
\text { (Anorganik) } \\
\text { Hortigro A }\end{array}$ & $5 \mathrm{ml} / \mathrm{L}$ air & 0.27 & 0.23 \\
$\begin{array}{c}\text { (Anorganik) } \\
\text { Multitonik }\end{array}$ & $3 \mathrm{gr} / \mathrm{L}$ air & 1.58 & 2.32 \\
$\begin{array}{c}\text { (Organik) } \\
\text { Supermes } \\
\text { (Organik) }\end{array}$ & $2 \mathrm{ml} / \mathrm{L}$ air & 0.95 & 1.51 \\
\hline
\end{tabular}

\section{Tinggi tanaman}

Nilai EC yang tinggi pada perlakuan $A b$ mix meningkatkan tinggi tanaman seiring bertambahnya umur tanaman. Tingginya nilai EC $(1,58-2,32)$ $\mathrm{mS} / \mathrm{cm}$ menghasilkan tinggi tanaman paling maksimal, pada perlakuan Ab mix menandakan bahwa unsur hara yang tersedia dan diserap oleh tanaman lebih tinggi dibandingkan perlakuan kontrol, hortigro $\mathrm{A}$, multitonik, dan supermes. EC yang tinggi menyediakan garam terlarut yang lebih banyak dibandingkan EC yang rendah, sehingga kebutuhan unsur hara tanaman selama proses pertumbuhan tersedia dalam jumlah banyak.

\section{Pengaruh EC Terhadap Tinggi Tanaman}

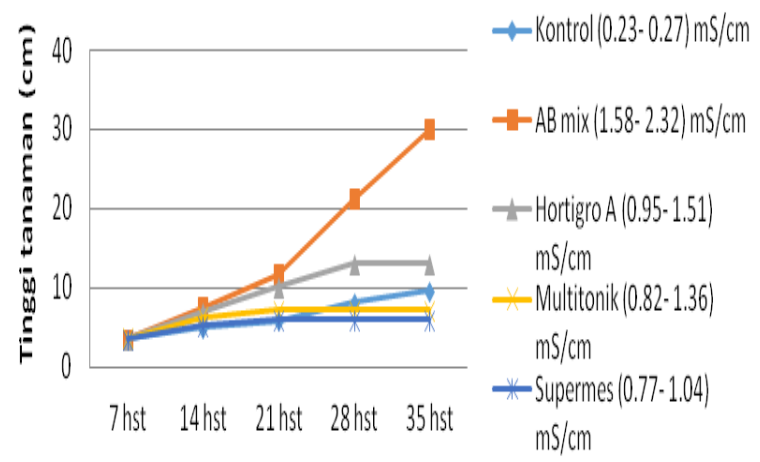

Gambar 1. Grafik pengaruh EC terhadap pertumbuhan tinggi tanaman kangkung darat 
Unsur hara Nitrogen banyak berperan dalam memacu pertumbuhan batang dan daun (Lingga, 2005). Selain unsur N, unsur mangan dan molibdenum juga berperan penting untuk mendukung pertumbuhan tanaman yaitu mangan $(\mathrm{Mn})$ berperan mendukung penyerapan nitrogen dan molibdenum (Mo) mengikat nitrogen.

\section{Luas Daun}

Pada Tabel 2 menunjukkan bahwa luas daun pada perlakuan Abmix memberikan hasil berbeda nyata dan tertinggi jika dibandingkan perlakuan yang lain. Tingginya luas daun dapat dipengaruhi oleh jumlah daun dan ukuran daun pada tanaman. Hal ini karena daun yang terbentuk dari $E C A B$ mix $1.58-2.32 \mathrm{mS} / \mathrm{cm}$ tercukupi kebutuhan haranya untuk membentuk jumlah daun sehingga daun semakin berkembang dan bertambah ukuran. Unsur hara yang berperan terhadap luas daun yaitu hara $\mathrm{N}$, unsur $\mathrm{N}$ sangat berkaitan dengan sintesis klorofil dan sintesis protein maupun enzim, berperan sebagai katalisator daun dan fiksasi $\mathrm{CO}_{2}$ yang dibutuhkan tanaman untuk fotosintesis (Subandi et al., 2015). Jika kekurangan unsur hara makro tersebut maka yang terjadi adalah fotosintesis berjalan lambat sehingga pembentukan daun tidak optimal, jika pembentukan daun tidak optimal maka luasan daun tanaman juga tidak optimal.

Tabel 2. Pengaruh nilai EC terhadap luas daun tanaman kangkung darat.

\begin{tabular}{lc}
\hline \multicolumn{1}{c}{ Perlakuan } & 35 HST \\
\hline Tanpa Pupuk $(0.23-0.27) \mathrm{mS} / \mathrm{cm}$ & $2,04 \mathrm{~b}$ \\
AB mix $(1.58-2.32) \mathrm{mS} / \mathrm{cm}$ & $13,16 \mathrm{a}$ \\
Hortigro A $(0.95-1.51) \mathrm{mS} / \mathrm{cm}$ & $2,81 \mathrm{~b}$ \\
Multitonik $(0.82-1.36) \mathrm{mS} / \mathrm{cm}$ & $1,90 \mathrm{~b}$ \\
Supermes $(0.77-1.04) \mathrm{mS} / \mathrm{cm}$ & $2,15 \mathrm{~b}$ \\
\hline
\end{tabular}

Keterangan : Angka - angka yang diikuti oleh huruf yang sama menunjukan pengaruh yang tidak berbeda nyata antar perlakuan, sedangkan angka - angka yang diikuti dengan huruf yang berbeda menunjukan pengaruh yang berbeda nyata antar perlakuan.

\section{Jumlah daun}

Pertumbuhan jumlah daun yang terus meningkat (Gambar 2). Tingginya jumlah daun pada perlakuan $A B$ mix diduga terjadi karena peran unsur makro dan mikro yang cukup tersedia pada larutan nutrisi. Sedangkan perlakuan kontrol, hortigro A, multitonik, dan supermes pertumbuhan jumlah daun tidak pesat. Lambatnya pertumbuhan jumlah daun terjadi karena kandungan hara yang tersedia pada larutan rendah, terutama unsur $\mathrm{N}$ yang berfungsi untuk memacu pertumbuhan daun. Seperti yang diungkapkan Subandi et al. (2015) bahwa pada EC yang rendah unsur $\mathrm{N}, \mathrm{P}$ dan $\mathrm{K}$ akan rendah pula sehingga menyebabkan pertumbuhan dan perkembangan tanaman menjadi lambat. Unsur $\mathrm{N}$ merupakan unsur utama dari semua protein dan asam nukleat, sehingga jika unsur $\mathrm{N}$ tersedia dalam jumlah yang cukup maka akan menghasilkan protein yang lebih banyak untuk meningkatkan pertumbuhan daun (Pratama, 2016).

\section{Pengaruh EC terhadap Jumlah Daun}

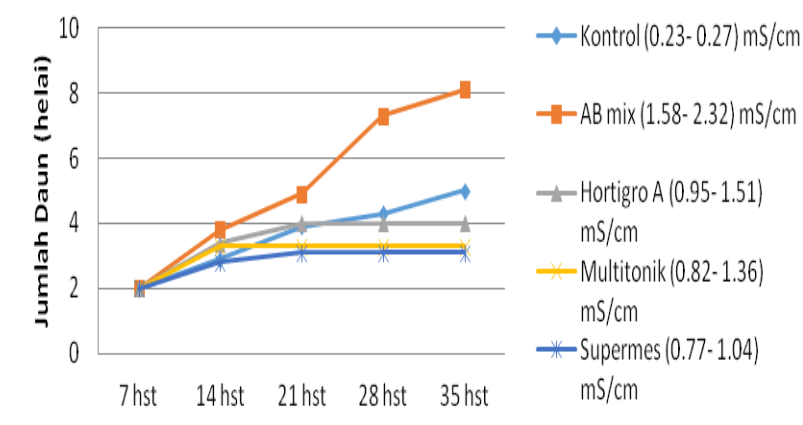

Gambar 2. Grafik pengaruh EC terhadap jumlah daun tanaman kangkung darat

\section{Diameter Batang}

Pada Tabel 3 menunjukkan bahwa diameter batang pada semua perlakuan berbeda nyata, EC 1.58 - $2.32 \mathrm{mS} / \mathrm{cm}$ pada perlakuan $A B$ mix menghasilkan diameter batang tertinggi. Proses translokasi unsur hara yang berjalan lancar mempengaruhi aktifitas pembelahan dan perpanjangan sel. Laju pembelahan sel dan perpanjangan serta pembentukan jaringan mempengaruhi pertumbuhan batang, daun dan akar (Harjadi, 1991). Selain itu jumlah daun yang meningkat akan mempengaruhi pertumbuhan batang tanaman. Karena daun yang banyak menghasilkan fotosintat yang berfungsi untuk pertumbuhan organ tanaman yang lain, salah satunya batang tanaman.

Tabel 3. Pengaruh nilai EC terhadap diameter batang tanaman kangkung darat.

\begin{tabular}{lc}
\hline \multicolumn{1}{c}{ Perlakuan } & 35 HST \\
\hline Tanpa Pupuk $(0.23-0.27) \mathrm{mS} / \mathrm{cm}$ & $2,24 \mathrm{bc}$ \\
AB mix (1.58 - 2.32) $\mathrm{mS} / \mathrm{cm}$ & $5,63 \mathrm{a}$ \\
Hortigro A (0.95 - 1.51) $\mathrm{mS} / \mathrm{cm}$ & $2,27 \mathrm{~b}$ \\
Multitonik (0.82 - 1.36) $\mathrm{mS} / \mathrm{cm}$ & $1,75 \mathrm{c}$ \\
Supermes $(0.77-1.04) \mathrm{mS} / \mathrm{cm}$ & $2,00 \mathrm{bc}$ \\
\hline
\end{tabular}

Keterangan : Angka - angka yang diikuti oleh huruf yang sama menunjukan pengaruh yang tidak berbeda nyata antar perlakuan, sedangkan angka - angka yang diikuti dengan huruf yang berbeda menunjukan pengaruh yang berbeda nyata antar perlakuan.

\section{Berat segar tanaman}

Perlakuan $A B$ mix dengan nilai $E C$ yang mencukupi kebutuhan hara memberikan hasil yang berbeda nyata (Tabel 4). Hasil tanaman dipengaruhi oleh faktor pertumbuhan seperti tinggi tanaman, jumlah daun, luas daun, dan diameter batang. Semakin baik pertumbuhan tanaman kangkung, maka akan semakin meningkatkan berat segar. Menurut Rahmah (2014) adanya peningkatan biomassa dikarenakan tanaman menyerap air dan hara lebih banyak,unsur hara memacu perkembangan organ pada tanaman seperti akar, sehingga tanaman dapat menyerap hara dan air lebih banyak selanjutnya aktifitas fotosintesis akan meningkat dan mempengaruhi peningkatan berat basah dan berat kering tanaman. Menurut Bhaskoro et al. (2015) Serapan hara $N$ yang tinggi mampu 
membuat hasil tanaman menjadi maksimal. Sehingga hal ini mengindikasikan bahwa pupuk $A B$ mix dengan nilai EC 1.58 - $2.32 \mathrm{mS} / \mathrm{cm}$ memberikan suplai hara $\mathrm{N}$ yang cukup untuk pertumbuhan dan perkembangan tanaman kangkung darat. Sedangkan perlakuan lain dengan nilai EC dibawah $1,5 \mathrm{mS} / \mathrm{cm}$, dapat diindikasikan bahwa unsur $\mathrm{N}$ tidak tersedia dalam jumlah yang banyak.

Tabel 4. Pengaruh nilai EC terhadap berat segar atas (BSA) tanaman kangkung darat.

\begin{tabular}{lc}
\hline \multicolumn{1}{c}{ Perlakuan } & BSA 35 HST \\
\hline Tanpa Pupuk (0.23 - 0.27) $\mathrm{mS} / \mathrm{cm}$ & $46,23 \mathrm{~b}$ \\
AB mix (1.58 - 2.32) $\mathrm{mS} / \mathrm{cm}$ & $388,85 \mathrm{a}$ \\
Hortigro A (0.95 - 1.51$) \mathrm{mS} / \mathrm{cm}$ & $28,63 \mathrm{c}$ \\
Multitonik (0.82 - 1.36) $\mathrm{mS} / \mathrm{cm}$ & $11,36 \mathrm{~d}$ \\
Supermes (0.77 - 1.04) $\mathrm{mS} / \mathrm{cm}$ & $13,34 \mathrm{~d}$
\end{tabular}

Keterangan : Angka - angka yang diikuti oleh huruf yang sama menunjukan pengaruh yang tidak berbeda nyata antar perlakuan, sedangkan angka - angka yang diikuti dengan huruf yang berbeda menunjukan pengaruh yang berbeda nyata antar perlakuan.

\section{KESIMPULAN}

Pemupukan meningkatkan nilai EC larutan hidroponik, nilai EC larutan tidak sama pada jenis pupuk yang berbeda dan nilai EC mempengaruhi parameter pertumbuhan tanaman kangkung (tinggi tanaman, jumlah daun, luas daun, diameter batang dan berat segar tanaman). Pupuk AB mix (Anorganik) dengan nilai EC (1.58 - 2.32) $\mathrm{mS} / \mathrm{cm}$ memberikan hasil pertumbuhan yang terbaik, yaitu menghasilkan rata - rata tinggi tanaman $(30,01 \mathrm{~cm})$, jumlah daun ( 8,1 helai), luas daun $\left(13,16 \mathrm{~cm}^{2}\right)$, diameter batang $(5,63 \mathrm{~mm})$, dan berat segar $(385,8 \mathrm{gr})$.

\section{DAFTAR PUSTAKA}

Bhaskoro, A. W., Novalia, K., \& Syekhfani. (2015). Efisiensi pemupukan nitrogen tanaman sawi pada inceptisol melalui aplikasi zeolit alam. Jurnal Tanah dan Sumberdaya Lahan 2 (2) : 219-226.

Dyka, T. A. (2018). Pengendalian pH dan EC Pada Larutan Nutrisi Hidroponik Tomat Ceri. Tugas
Akhir. Jurusan Sistem Komputer, Instititut Bisnis dan Informatika Stikom Surabaya.

Harjadi. (1991). Pengantar Agronomi. Gramedia Pustaka Utama. Jakarta.

Lingga, P. (2005). Hidroponik Bercocok Tanam Tanpa Tanah. Penebar Swadaya, Jakarta.

Pratama, A. (2016). Pengaruh Berbagai Macam Medium Tanam dan Konsentrasi POC Urine Sapi Pada Pertumbuhan dan Hasil Caisim Dengan Sistem Wick Pot Hidroponik. Skripsi. Fakultas Pertanian Universitas Muhammadiyah Yogyakarta.

Savvas, D., Tuzel, Y., Gianquinto, G., \& Gruda, N. (2013). Good Agricultural Practices For Greenhouse Vegetable Crops - Principles Form Mediterranean Climate Areas. FAO Publication Online.

Subandi, M., Salam, N. P., \& Frasetya, B.. 2015. Pengaruh berbagai nilai EC (Electrical Conductivity) terhadap pertumbuhan dan hasil bayam (Amaranthus sp.) pada hidroponik sistem rakit apung (floating hidroponics system). Jurnal Agroekoteknologi 9 (2) : 136-152.

Sutiyoso, Y. (2004). Hidroponik ala Yos. Penebar Swadaya, Jakarta

Swastini, N. M. (2015). Pengaruh Arang Sekam Sebagai Media Tanam Terhadap Pertumbuhan Tanaman Kangkung Darat (Ipomoea reptans Poir). Skripsi. Program Studi Pendidikan Biologi. Fakultas Keguruan dan IImu Pendidikan Universitas Sanata Dharma, Yogyakarta.

Tim Karya Tani Mandiri. (2010). Pedoman Budidaya Secara Hidroponik. CV Nuansa Aulia, Bandung.

Wibowo, A. W., Suryanto, \& Nugroho. 2017. Kajian Pemberian Berbagai Dosis Larutan Nutrisi dan Media Tanam Secara Hidroponik Sistem Substrat Pada Tanaman Kailan. Jurnal Produksi Tanaman $5(7): 1119-1125$. 